\title{
IMPLEMENTATION OF LAW ENFORCEMENT AGAINST CRIME WITH SMALL MOTIVE PATTERNED RESTORATIVE JUSTICE IN POLICE SECTOR GAYAMSARI OF SEMARANG CITY
}

\author{
Andri Winjaya Laksana \\ Sultan Agung Islamic University Semarang \\ andriwinjaya@gmail.com \\ Sisca Dyah Octaviani \\ Sultan Agung Islamic University Semarang \\ siscapolwandtn@gmail.com
}

\begin{abstract}
Crime and violations in the community are increasing. Reviews of these actions are very detrimental to society, so that the law needs to be enforced. Law enforcement in Indonesia has not provided a sense of justice for the community, especially for mild crimes, so that Appropriate Efforts are needed items, namely with a approach to restorative justice in resolving them. Police are the frontline in law enforcement in Indonesia. The community hopes that the police can quickly intervening handle mild cases of criminal offenses that occur in the community, by making Efforts not to harm both parties, using a restorative justice approach through Deliberation.
\end{abstract}

Keywords: Law Enforcement; Minor crime Motive; Police Sector; and Restorative Justice.

\section{A. INTRODUCTION}

Criminal cases in Indonesia continues to increase, how is seen in television media and electronic media regarding the news about crimes such as murder, torture, corruption, theft, and so must be aware society, it could disrupt security and public order.

The criminal offenses and sentencing are the terms of the law which is as warm to be discussed from time to time. It is caused by the characteristics and formulation continues to change in line with the pattern of development of society and the technological sophistication as a manifestation of the development of science. ${ }^{1}$

Criminal activity plaguing the society, then such actions should be dealt with firmly, and it is the duty of the law which has the function to create and maintain order and all in community life, as the adage " ubi societas ibi ius ", (in where there are people there is the law). If the law is not placed as a legal basis to act in a country, then the atmosphere of life in society, it will be chaotic conflict can occur even between them. 2

1 Teguh Prasetyo dan Abdul Halim Barkatullah, Politik Hukum Pidana, Kajian Ke-bijakan Kriminalisasi Dan Dekriminalisasi, Cetakan Kedua, Pustaka Pelajar, Yogyakarta, 2005, p. v.

2 Jawade Hafidz Arsyad dan Dian Karisma, Sentralisasi Birokrasi Pengadaan Barang \& Jasa Pemerintah, Cetakan Pertama, Sinar Grafika, Jakarta, 2018, p. 25. 
Type any criminal offense, which is a criminal offense or crimes like murder or such violations, and there is a mention of crime / criminal acts such as theft and minor crime patterned, everything must be done prosecution. The offender must obtain criminal sanctions in accordance with his deeds. However, such a crime, offense or offenses patterned minor crime having different sanction of course, and a minor crime patterned criminal offenses can not be equated with a criminal sanction criminal acts which cause serious injury to the victim.

Misdemeanor own sense is not regulated in the Criminal Code. Wirjono Pradjodikoro in his book " Asas-Asas Hukum Pidana Di Indonesia" states that in the Criminal Code there are several criminal offenses concerning property (vermogendelicten), if the loss caused not exceed twenty-five rupiah, called "minor crimes" (lichte misdren) and only punishable by severe as imprisonment for 3 months. 3

The state has an important role in the decision-to-decision against criminal offenders, ie the offender. The state has taken over the conflict between members of one community with the other members of the community, ie, to the perpetration of offenses can harm other people and countries through the criminal justice system.

In the conventional criminal justice system always involves and includes a subsystem with the scope of their respective judicial process, namely: the police, prosecutors, courts, prisons, and lawyer. ${ }^{4}$

The criminal justice system that starts from the investigation stage to the stage of the examination at the trial, which ended with a verdict stating guilt or innocence of the accused requires considerable time and cause a buildup of a court, and me to add a load in prisons so that in case handling criminal needs to be solved in different ways between ordinary crime and criminal offenses which is patterned minor crime.

An example is in the case of minor crime-motivated criminal offenses, namely mild persecution. Persecution is a crime that often occur in the community. The persecution is not only due to the desire to judge someone on-suspected offender by the victim, but can also be caused due to trivial matters, for example, words that make a person offended so committed abuses and acts of others that can cause sores on a person's body, although as a result of the abuse does not lead to the death of the victim.

Sub-systems within the criminal justice system that is spearheading uncover a criminal case is the police. Essentially, the scope of duties and functions of police agencies governed Act No. 2 of 2002 on the Indonesian National Police and the Criminal Procedure Code. As law enforcement agencies, and based on the Criminal Code, essentially the police conduct the investigation in a criminal case. ${ }^{5}$

In the case of mild persecution crime which is per-artificial person against another person that resulted in injuries is the duty of investigators should endeavor to reveal the persecution crime occurred and found the suspects. Against the crime of persecution minor crime only lead to injuries is not appropriate if the offender was sentenced by criminal sanctions is equal to the crime of aggravated assault, so that the impact of the act actors

3 Jonlar Purba, Penegakan Hukum Terhadap Tindak Pidana Bermotif Ringan Dengan Restorative Justice, Cetakan Pertama, Jala Permata Aksara, Jakarta, 2017, p. 4 dan 5.

4 Sidik Sunaryo, Kapita Selekta Sistem Peradilan Pidana, Cetakan Ketiga, UMM Press, Malang, 2005, p. 220.

5 Lilik Mulyadi, Kapita Selekta Hukum Pidana, Kriminologi \& Victimologi, Djambatan, Jakarta, 2004, p. 3. 
only result in injury to the victim, if it were simply compensation for recovery health of the victim, and do not need to be resolved through legal channels.

Law enforcement run without the selection of the case, namely the ordinary crime patterned minor crime, it has acquired social reactions from society because of interference to the sense of justice of the means of settlement of ordinary crime patterned minor crime which does not give space in ways that non-formal settlement or through unlawful.

Changing views about fairness in the criminal law take on a change of mindset in handling the problems of crime. Restorative justice is an alternative to the settlement of criminal acts directed at an informal settlement or out of court, with the involvement of all parties involved in the criminal act has occurred, in which the completion of the crime has evolved in some countries in tackling crime. 6 Restorative justice system at least aim to improve / restore (to restore) criminal acts committed by the child's air action benefits for children, the victims and the environment. 7

In the implementation of law enforcement by using restorative justice as stated by Oliver Wendell Holmes, with the idea that famous formulation of "The life of the law has not been logic it has been experience", which was then elaborated further by Satjipto Raharjo that law enforcement officers should not only "spelling rules" per se, but explore the values contained in the legislation. To that end, law enforcement officers are required to empower all the capacity in him, not only in itself but with concern ratio (compassion), empathy, sincerety and courage (dare). ${ }^{8}$

Restorative justice approach is a paradigm that is used as a frame of a strategy for handling criminal cases, which aims to answer dissatisfaction over the working of the system per-justice criminal that exists today, where the process of settlement of the criminal case is conventionally very complicated, require a long time to arrive at a decision by the judge even not necessarily have justice or satisfaction expected by the litigants. Restorative justice is a concept thought to respond to the development of the criminal justice system by focusing on the needs of community engagement and the victims were deemed excluded by mechanisms that work in the criminal justice system that exists today. 9

As for the use of restorative justice in the resolution of ordinary crime motivated minor crime used theory put forward by Tony Marshall, namely: "Restorative justice is a process whereby all the parties with a stake in a particular offense come together to resolve Collectively how to deal with the aftermath of the offense and its implications for the future ". Free translation: Restorative justice is a process in which all parties involved in a particular criminal act together to find a solution jointly seek the solution in the face of

6 Hadi Supeno, Kriminalisasi Anak : Tawaran Gagasan Radikal Peradilan Anak Tanpa Pemidanaan, Gramedia Pustaka Utama, Jakarta, 2010, p. 17.

7 Sri Rahmi, Aswanto, dan Muh. Syukri, Penerapan Keadilan Restoratif Dalam Sistem Peradilan Pidana Anak Di Kota Makasar (Suatu Pembaruan Hukum Acara Pidana Anak), Fakultas Hukum Program Pascasarjana Universitas Hasanuddin, Makasar, Tanpa Tahun, p. 4.

8 Jonlar Purba, op.cit., p. 13.

9 Ibid.,p. 14 and 15. 
events subsequent to the onset of the offense as well as how to cope with the implications for the future. ${ }^{10}$

As cases of mild persecution crime handled by the Police Sector Gayamsari Semarang completed with restorative justice mechanisms, which ended with the provision of compensation by the offender to the victim. In such cases, the investigating police sector Gayamsari Semarang implement restorative justice mechanisms through consultation between the offender and the victim to come to an agreement. Accordingly, the police have used his authority to stop the case being forwarded through the legal system through restorative justice mechanisms. Based on the above description, the author formulate several problems, namely:

1. How is the implementation of law enforcement against criminal acts minor crime patterned with restorative justice in police sector Gayamsari Semarang?

2. How barriers and enforcement solutions to the crime of minor crime patterned with restorative justice in police sector Gayamsari Semarang?

\section{B. RESEARCH METHODS}

The approach used in this study is a method socio-juridical, that in addition to using the principles and legal principles in reviewing, view, and analyze the problems, this study also review how its implementation in practice. 11 This study is a descriptive analysis, because the researcher wishes to re-describe or explain on the subject and the object of research, which is then analyzed and finally the conclusions drawn from the research.12

The data used in this study are primary data and secondary data. Primary data is data obtained primarily from the sociological research, that is performed directly in the community, the technique used is the interview with the investigator in the police sector Gayamsari Semarang. Secondary data is data obtained from ingredients Pusta-ka through the study of literature, and these data were also obtained from institutions / agencies related to the goals of this research. 13 Secondary data include primary legal materials, secondary law, and tertiary legal materials. The data collected in this study are primary data and secondary data obtained through field studies and literature. According to data that have been obtained from the field study, the research is a socio-juridical, with the data obtained through interviews and from literature studies by reading library books, then do analysis. Analysis magnified use in this thesis is a qualitative analysis.

\section{DISCUSSION}

1. Implementation of law enforcement against criminal acts minor crime patterned with restorative justice in police sector Gayamsari Semarang;

10 Ibid., p. 25.

11Ronny Hanitijo Soemitro, Metodologi Penelitian Hukum dan Jurimetri, Ghalia Indonesia, Jakarta, 1990, p. 33.

12Mukti Fajar ND dan Yulianto Achmad, Dualisme Penelitian Hukum Normatif dan Empiris, Pustaka Pelajar, Yogyakarta, 2010, p. 183.

13 Soeratno dan Lincolin Arsyad, Metodologi Penelitian Untuk Ekonomi Dan Bisnis, UPP AMP YKPN, Yogyakarta, 2003, p. 173. 
The completion of the criminal case is done through the criminal justice system, where criminal justice has powers of its unusually large, ranging from police, prosecutors, the judiciary, and institution-Detention pemasya. Criminal justice has a fundamental responsibility to the public interest, namely the extent to which the actions or judgments that are issued judicial (criminal) accountable to the people.

In the criminal justice process, the most important task of the law enforcement is to find the material truth, the real truth. Such a task is not easy for the case because the investigator, prosecutor, or judge not me around and watched with my own eyes how the occurrence as well as who the culprit. ${ }^{14}$

However, law enforcement is always working fully to reveal the truth of a criminal incident to locate the suspects and provide criminal sanctions for the offender to provide a deterrent effect and change the behavior of the offender to be received by the public.

In order to convict a person as well as meet the demands of justice and humanity there should be an act which is contrary to the law and that can be blamed on the culprit. Actors concerned must be someone who can be held responsibility (toerekeningsvatbaar) or schuldfahig. ${ }^{15}$

As we know that the criminal justice stipulated in the Criminal Code and its implementing regulations, and based on per-laws rules and regulations, then the criminal justice process is divided into several levels, namely: ${ }^{16}$

a. The level of investigation by the investigator;

b. The level of investigation and additional investigation by the investigator;

c. The level of prosecution by the public prosecutor;

d. Level examination in court by the judge.

Here, the police spearheading the air-like disclosure of criminal cases, including here is a criminal offense patterned minor crime as minor crime maltreatment. The police as law enforcers have the daunting task of dealing with a criminal offense. ${ }^{17}$ The police have a very important role in uncovering and dealing with various forms of crime. The main role of the police is when identifying a person, whether a person is a criminal or a victim to find the person's identity by conducting investigations and inquiries. The position of the police in the middle of the community are always faced with different challenges.

Society certainly crave all aspects of life in society can be governed by the laws and issues that arise can be solved as well as possible without harm to either party, and all the issues expected to be resolved equitably accompanying legal basis.

14 Sofwan Dahlan, IImu Kedokteran Forensik Pedoman Bagi Dokter dan Penegak Hukum, Badan Penerbit Universitas Diponegoro, Semarang, 2000, p. 13.

15 Jan Remmelink, Hukum Pidana Komentar Atas Pasal-pasal Terpenting dari Kitab Undang-Undang Hukum Pidana Belanda dan Padanannya dalam Kitab Undang-Undang Hukum Pidana Indonesia, Gramedia Pustaka Utama, Jakarta, 2003, p. 85 dan 86.

16 Sofwan Dahlan, Ibid., p. 13.

17 Yuarsi Susi Eja, et.al., Menggagas Tempat yang Aman Bagi Perempuan, Pusat Studi Kependudukan dan Kebijakan Universitas Gajah Mada, Yogyakarta, 2002, p. 13. 
Indonesian National Police (POLRI) is the frontline of the law enforcement component, in addition to prosecutors, judges, and lawyers. Police as the spearhead of law enforcement, has a position and a very important role, namely as the keeper of security, the implementation is to prevent and cope with a crime and violations that occur in the community.

In addition, as a police state apparatus or law enforcement officials have a service function, which is in charge of maintaining public order and as the public protector. The existence of the police as a component of law enforcement in Indonesia is very important in maintaining stability and order in society, nation and state.

Indonesian National Police is the law enforcement officers who often interact with members of the community. Villagers often encounter members of the police carry out their duties throughout all kinds of law enforcement as well as providing care to society. 18

Indonesian National Police as one of the government institutions that served as the spearhead of law enforcement in Indonesia, has the task which is not minor crime because of dealing directly with the public.

One of the functions of their duties is to assist communities in addressing social problems in the environment and in order to prevent disturbance to public order and safety. Cooperation between police and the public good, it is expected all the conflicts or problems that occur in society can be settled amicably or out of court, with wrap-right perpetrators, victims, families of victims and perpetrators, the public as well as members of the police, known as restorative justice,

Restorative justice is a way of conflict resolution is more focused on solving problems that involve more extensive, such as the involvement of the victim and the community.

The application of restorative justice in the resolution of conflicts in society more benefits than the settlement of the problem through legal channels, which the resolution of conflicts through legal means lack of involvement of victims and the community to jointly solve case or the ongoing conflict. However, in the field of criminal law, the peaceful resolution of cases through as yet difficult to implement.19

One form of settling disputes through restorative justice approach is through negotiation or mediation. According to Jeff Knight that the deliberations in the completion of the criminal case through a restorative justice approach is always directed towards satisfaction of all parties, and can be realized by the offender. ${ }^{20}$

18 Ira Alia Maerani, Re-actualizing process of investigation by the Police-Based values of Pancasila and Optimizing Utilization of Technology, Law Journal, Vol. XXXII, No. 2, Faculty of Law, University Islam Sultan Agung (UNISSULA), Semarang, December 2015, p. 1738.

19 Andri Winjaya Laksana, Keadilan Restoratif Dalam Penyelesaian Perkara Anak yang Berhadapan Dengan Hukun Dalam Sistem Peradilan Pidana Anak, Jurnal Pembaharuan Hukum, Volume IV No. 1, JanuariApril 2017, p. 58.

20 Natangsa Surbakti, Peradilan Restoratif Dalam Bingkai Empiri, Teori dan Kebijakan, Cetakan Kesatu, Genta Publishing, Yogyakarta, 2015, hlm. 51. 
An example is the case of minor crime-motivated criminal acts, namely the acts of persecution minor crime handled by police sector Gayamsari Semarang, which can be solved by using the concept of restorative justice approach involving the perpetrator, the victim, the community and the police (investigator) by consensus the following:

\begin{tabular}{|c|c|c|c|}
\hline No. & Performer & Article & Chronological \\
\hline 1. & AM & $\begin{array}{l}\text { Article } 351 \text { of the } \\
\text { Criminal Code }\end{array}$ & $\begin{array}{l}\text { The incident occurred on Friday, } 3 \\
\text { November } 2017 \text { at approximately } \\
13: 00 \text { pm in the parking area next to } \\
\text { the North of the Great Mosque of } \\
\text { Central Java. Done AM Friday prayers } \\
\text { along with two (2) a friend of his } \\
\text { named HR and SUL break at a shop } \\
\text { near the parking lot north of the Great } \\
\text { Mosque of Central Java with ordered } \\
\text { iced tea to shopkeepers, then } \\
\text { suddenly there's office boy } \\
\text { (rapporteur) who are me-sweep, } \\
\text { where garbage is directed toward AM } \\
\text { and friends, then AM said: "Please } \\
\text { mas, the dust of his entry in ice } \\
\text { glasses and eye my friend", the } \\
\text { complainant did not respond said late } \\
\text { AM and said "if you do not want to be } \\
\text { a broom do not sit there", then the } \\
\text { complainant quarreled with HR, and } \\
\text { AM's emotions immediately took a } \\
\text { plank of wood under the seat and } \\
\text { hitting the reporting of } 1 \text { (one) and } \\
\text { resulting in the right temple and } \\
\text { pulled the complainant injured } \\
\text { bleeding, then AM discard the wooden } \\
\text { board and the complainant then } \\
\text { hitting AM using a broom stick he was } \\
\text { carrying, and he hit his head and neck } \\
\text { to the left of the left of AM resulting in } \\
\text { head AM sick, then the complainant } \\
\text { intends to throw stones in the } \\
\text { direction of the AM and hit the right } \\
\text { arm AM, then the complainant will } \\
\text { throw more stones by AM friends } \\
\text { shouting to the AM "AM sighted" } \\
\text { hereinafter AM flee and the stone was } \\
\text { unsuccessful regarding the AM, then } \\
\text { friends of the complainant who is the } \\
\text { same as the cleaning service came }\end{array}$ \\
\hline
\end{tabular}




\begin{tabular}{|c|c|c|c|}
\hline & & & $\begin{array}{l}\text { and beat } A M \text { and friends who thought } \\
\text { his friend had been attacked by the } \\
\text { PM and his two friends, then because } \\
\text { he felt threatened by } A M \text { escape to } \\
\text { post security and be secure in the } \\
\text { post. }\end{array}$ \\
\hline 2. & MWP & $\begin{array}{l}\text { Article } 351 \text { of the } \\
\text { Criminal Code }\end{array}$ & $\begin{array}{l}\text { The incident occurred on Saturday } 16 \\
\text { September } 2017 \text { date approximately } \\
04.00 \text { am on Jl. Unta Semarang } \\
\text { (forward power plant). MWP when it } \\
\text { was looking at his building on Jl. Unta } \\
\text { Semarang and MWP position being on } \\
\text { the road, then from the north coming } \\
1 \text { (one) unit of the car and is } \\
\text { approximately } 500 \text { m approaching. } \\
\text { The car turn on the minor crimes } \\
\text { rotator, rang serine and horn } \\
\text { repeatedly, then the car is out of the } \\
\text { way at the edge of the road after me- } \\
\text { see MWP and reporter / driver that me } \\
\text { calling out MWP and say "whats up } \\
\text { bro" and MWP ask back " whats up } \\
\text { bro too" then the complainant / } \\
\text { driver MWP estimate was drunk } \\
\text { suddenly it held a kind of gun that } \\
\text { MWP estimate is kind softgun, then } \\
\text { MWP will seize objects that are similar } \\
\text { to a firearm (pistol) are and will be } \\
\text { "tried to pull an", then MWP try open } \\
\text { the door, but the driver to lock the } \\
\text { door and then with the intention of } \\
\text { securing objects that are similar to a } \\
\text { firearm (pistol) of the reporting / } \\
\text { driver MWP thought he was drunk the } \\
\text { camp happen "tug-of-war" that might } \\
\text { inadvertently hand MWP on face } \\
\text { rapporteurs / driver and then the } \\
\text { complainant / driver is successfully } \\
\text { MWP out, and MWP ask is where } \\
\text { objects that are similar to firearms } \\
\text { (sofgun) that is used to re-threatened, } \\
\text { but the complainant / drivers are not } \\
\text { admitted and later by local residents } \\
\text { issued two driver friend who was in } \\
\text { the car and also look for objects that } \\
\text { are similar to a firearm (pistol) in a car } \\
\text { and managed to find sofgun securing } \\
\text { it, and id card in the reporting clothes }\end{array}$ \\
\hline
\end{tabular}




\begin{tabular}{|l|l|l|}
\hline & $\begin{array}{l}\text { / driver kept MWP together with } \\
\text { objects similar to a firearm (pistol), } \\
\text { and reporter / driver along with his } \\
\text { two friends by residents told to go } \\
\text { home. }\end{array}$ \\
\hline
\end{tabular}

Of the two cases of criminal acts of persecution minor crime handled by police sector Gayamsari Semarang, using restorative justice approach through consultation carried out by the investigating police sector Gayamsari, both sides are the perpetrators and the complainant or victim is not willing to not renew the problem, and will be resolved in a way fine.

In the handling of criminal cases were patterned minor crime, police sector Gayamsari try to resolve his case in discussion involving the perpetrator, the victim, and the community. Involvement of the perpetrator, the victim, and the community in dealing with conflicts or criminal cases can raise awareness of the public in general to prefer settling disputes through consultation and will be the responsibility of the perpetrator for his actions and fostering of public awareness. 21

In handling the criminal case patterned minor crime, then the police sector Gayamsari will provide insight for the parties to resolve the matter amicably as the implementation of the concept of restorative justice. Based on the agreement of the parties, police sector Gayamsari submit the settlement to the parties, and police sector Gayamsari act as a facilitator and mediator for the parties. 22

Forms of restorative justice are solved by police sector Gayamsari form of consultation or mediation by the parties and witnesses and community leaders, offer the right solution for the parties in the conflict, so as to provide all restlessness for the parties to a win-win solution, provides an overview of law and the legal consequences caused when the case was forwarded to the court, but can be settled out of court. 23

Completion patterned criminal case that minor crime, all the parties involved stand the perpetrator, the victim, the community and law enforcement are parallel. The parties involved should endeavor to find a solution that is fair to all parties with no harm either party, then exit it can be contained in a form of a peace treaty. ${ }^{24}$

The following can be presented the contents of the agreement were agreed by the parties, both perpetrators and victims in criminal lawyer of minor crime as mentioned above:

\begin{tabular}{|c|l|c|l|}
\hline No. & performer & Article & \multicolumn{1}{|c|}{ Fll Agreement } \\
\hline 1. & AM & $\begin{array}{l}\text { Article 351 of the } \\
\text { Criminal Code }\end{array}$ & $\begin{array}{l}1 . \quad \text { On Friday, 3 November 2017 } \\
\text { at 23.00 am at the parking area north } \\
\text { of the Great Mosque of Central Java } \\
\text { Jl. Gajah Raya Semarang has }\end{array}$ \\
\hline
\end{tabular}

21 M. Bekti Umaiyah, Interviews, Criminal Police Investigator Gayamsari at Semarang, on February 26, 2019. 


\begin{tabular}{|c|c|c|c|}
\hline & & & $\begin{array}{l}\text { happened persecution carried out by } \\
\text { the first Party and second Party so I } \\
\text { suffered injuries in the right temple } \\
\text { (had requested the autopsy report); } \\
2 \text { That Party II has apologized to } \\
\text { the Party I, and Parties I have me- } \\
\text { forgive her; } \\
3 \text {. That Party II has given } \\
\text { compensation to the Party II in the } \\
\text { form of reimbursement for treatment } \\
\text { of Rp } 2,000 \text {. 000, - (two million) and } \\
\text { has been received by the Party I; } \\
4 \text { Party II was very sorry for } \\
\text { what he had done to the party I se-to- } \\
\text { inflicted second party, party I } \\
\text { Gayamsari complained to the Police; } \\
5 \text { After the incident Party II air- } \\
\text { promise not to repeat such actions to } \\
\text { anyone. }\end{array}$ \\
\hline 2. & MWP & $\begin{array}{l}\text { Article } 351 \text { of the } \\
\text { Criminal Code }\end{array}$ & $\begin{array}{l}\text { 1. On the day of Saturday, } \\
\text { September 16th, } 2017 \text { at } 04.00 \text { pm at } \\
\text { Jl. Unta Raya Pandean Lamper } \\
\text { Semarang, (forward power plant) has } \\
\text { occurred facing persecution carried } \\
\text { out by the Party I Party II so that } \\
\text { Parties I injured (already requested } \\
\text { the autopsy report); } \\
2 \text { That Party II has apologized to } \\
\text { the I and the party I have forgive her; } \\
\text { 3. That Party II has given } \\
\text { compensation to the Party II } \\
\text { pecuniary phone replacement and } \\
\text { repair of vehicles / cars Rp } 4,000.000 \text {, } \\
\text { - and has been accepted by the I; } \\
\text { 4. Party II was very sorry for } \\
\text { what he had done to the party I se-to- } \\
\text { inflicted second party, party I } \\
\text { Gayamsari complained to the Police; } \\
5 \text { After the incident, the Party II } \\
\text { not to repeat such actions to anyone. }\end{array}$ \\
\hline
\end{tabular}

Agreements made in writing by the parties (perpetrator and victim) was made in the presence of police investigators and witnesses at Gayamsari. The appointments were made with full awareness and without coercion or pressure from any party. 25 
The good faith of the parties (perpetrators and victims) to do collective agreement by written agreement entered into between the perpetrators and the victims and witnessed by the wider community in restorative justice has a very important role. Good faith in implementing the contents of the agreement will provide benefits for all parties and this will further ensure the fulfillment of a sense of injustice among all victims, offenders and communities, and still be able to prevent the perpetration of criminal acts in the future back. If the resolver's case to the approach or the concept of restorative justice not achieved, then the state in this case law enforcement has the authority to impose criminal sanctions to perpetrators. Thus, the criminal law and sentencing can be used as a last resort (ultimum remedium) ${ }^{26}$

2. Barriers and enforcement solutions to the crime of patterned minor crime with restorative justice in police sector Gayamsari Semarang.

As a frontline in the law enforcement process, then to - policing must seek ways in cases of criminal offenses which can be well handled without harming the parties, the one using restorative justice approaches that are done at the stage of investigation.

Restorative justice is the proper way to handle the issue or conflict. Restorative justice is a process of resolving a criminal case with the aim of achieving justice that is fully implemented and achieved by the offender, the victim, and the community at large. Stated so because the concept of restorative justice approach or come into one's vision a form of justice that emphasizes a process of involvement of all parties who are actively involved in a specific criminal offense.

Results of interviews with M. Bekti Umaiyah as Criminal Police Investigator of Gayamsari that the benefits of the application of restorative justice in the criminal case settlement patterned minor crime by police sector Gayamsari, among others: ${ }^{27}$

a. Can minimize the crime rate and reduce the burden of handling cases in the courts;

b. Can give peace and avoid resentment or hostility between the parties to the conflict;

c. Can teach the meaning of responsibility to the offender as a result of homemade;

d. Can eliminate the negative stigma against perpetrators of criminal acts; and

e. To increase awareness of the law for the citizens.

However, in the implementation of restorative justice in the criminal case settlement patterned minor crime by police sector Gayamsari there are obstacles, among which are: ${ }^{28}$

a. Police:

1. Lack of facilities or infrastructure to conduct the mediation effort or deliberation; 
2. Investigators could not convince the parties to resolve the case by way of deliberation.

b. The offender and the victim:

1. The conflicting parties are not willing to accept advice from investigator;

2. The criminal act had repeatedly occurred;

3. This lack of understanding does bears a lesaikan deliberations on the criminal case, because the parties assume a criminal case should be resolved in court; and

4. One party does not have good faith to implement the peace agreement that has been made.

Handling motivated criminal assault minor crime by police sector Gayamsari with the concept of restorative justice approach is more beneficial, especially that preferred conflict resolution through the efforts of peace, that will create a win-win solution. In addition, victims' rights, hopes and wishes will be magnified overdue and more considered, so that not only questioned the compensation issue to be obtained victims.

The apology by the offender to the victim is also very important, because the apology given by the victim, it will not cause problems later in the day and will not cause resentment, that will create peace within the community.

To overcome the obstacles in the implementation of all restorative justice in the criminal case completion of the patterned minor crime, it can be done efforts as follows: ${ }^{29}$

a. Police:

1. Add facilities or infrastructure that support the implementation of consultation or mediation in the settlement of case minor crime-motivated criminal acts;

2. Investigators continue to fully convince the conflicting parties to solve problem amicably.

b. The offender and the victim:

1. Provide education or socialization related to the early settlement of criminal matters by consensus;

2. More can calm the emotions to resolve conflicts;

3. Consistent and have good faith to implement the contents of per-pact of peace;

4. Provide sanctions for violating the terms of the agreement so that there are no losers.

Implementation of restorative justice in the criminal case accomplishing a patterned minor crime has been made at this time by police sector Gayamsari, so far no negative impacts, because the perceived benefits more than having to use conventional law.

29 Ibid. 


\section{CLOSING}

\section{CONCLUSION}

a. Implementation of law enforcement against criminal acts minor crime patterned with restorative justice in police sector Gayamsari Semarang do with the way discussions that involve the perpetrator, the victim, and the community. In this case the police sector Gayamsari: (a) to a give a view for the parties to resolve the matter amicably, (b) submit the settlement to the parties, (c) Police sector Gayamsari act as a facilitator and mediator for the parties, (d) offer the right solution for the parties in the conflict, so as to give peace to the parties with a win-win solution, (e) provide an overview of law and the legal consequences caused when the case was forwarded to the court, and (f) the results of the deliberations set out in a form of agreement in writing;

b. Barriers of law enforcement against criminal acts of patterned minor crime with restorative justice in police sector Gayamsari Semarang, among other things: (a) the police: (i) lack of facilities or infrastructure to conduct the mediation effort or deliberation, and (ii) the investigator can not convince the parties to settle the case with the discussion; (B) the offender and the victim: (i) the parties are not willing to accept the advice of the investigator, (ii) a criminal offense has repeatedly occurred, (iii) a lack of understanding of the parties on the resolution of criminal cases through consultation, (iv) one of the parties does not have a good faith to implement the peace agreement that has been made. The solution to these obstacles are: (a) the police: (i) add facilities and infrastructure that support the implementation of discussion or mediation in the settlement of criminal case the patterned minor crime, (ii) the investigator seeks to fully convince parties to solve problems amicably; (B) the offender and the victim: (i) provide education or socialization related to the settlement of criminal cases through consultation, (ii) more mute emotion to resolve the conflict, (iii) consistent and backs possess good faith to implement the contents of the agreement peace, and (iv) provide sanctions for violating the terms of the agreement so that there are no losers.

\section{SUGGESTION}

a. For legislators, should approach restorative justice a legal umbrella, so it is actually implemented in the process of law enforcement both at the level of investigation, prosecution wants-even in court. The concept of restorative justice approach to tackle criminal cases can be included in the new Criminal Code and Criminal Procedure Code, so that a clear legal basis;

b. For law enforcement, more priority to the implementation of restorative justice approach to all, and if it is not sought to be penalized. 


\section{BIBLIOGRAPHY}

\section{A. Books:}

Hadi Supeno, Kriminalisasi Anak : Tawaran Gagasan Radikal Peradilan Anak Tanpa Pemidanaan, Gramedia Pustaka Utama, Jakarta, 2010.

Jan Remmelink, Hukum Pidana Komentar Atas Pasal-pasal Terpenting dari Kitab Undang-Undang Hukum Pidana Belanda dan Padanannya dalam Kitab UndangUndang Hukum Pidana Indonesia, Gramedia Pustaka Utama, Jakarta, 2003.

Jawade Hafidz Arsyad dan Dian Karisma, Sentralisasi Birokrasi Pengadaan Barang \& Jasa Pemerintah, Cetakan Pertama, Sinar Grafika, Jakarta, 2018.

Jonlar Purba, Penegakan Hukum Terhadap Tindak Pidana Bermotif Ringan Dengan Restorative Justice, Cetakan Pertama, Jala Permata Aksara, Jakarta, 2017.

Lilik Mulyadi, Kapita Selekta Hukum Pidana, Kriminologi \& Victimologi, Djambatan, Jakarta, 2004.

Mukti Fajar ND dan Yulianto Achmad, Dualisme Penelitian Hukum Normatif dan Empiris, Pustaka Pelajar, Yogyakarta, 2010.

Natangsa Surbakti, Peradilan Restoratif Dalam Bingkai Empiri, Teori dan Kebijakan, Cetakan Kesatu, Genta Publishing, Yogyakarta, 2015.

Ronny Hanitijo Soemitro, Metodologi Penelitian Hukum dan Jurimetri, Ghalia Indonesia, Jakarta, 1990.

Sidik Sunaryo, Kapita Selekta Sistem Peradilan Pidana, Cetakan Ketiga, UMM Press, Malang, 2005.

Soeratno dan Lincolin Arsyad, Metodologi Penelitian Untuk Ekonomi Dan Bisnis, UPP AMP YKPN, Yogyakarta, 2003.

Teguh Prasetyo dan Abdul Halim Barkatullah, Politik Hukum Pidana, Kajian Kebijakan Kriminalisasi Dan Dekriminalisasi, Cetakan Kedua, Pustaka Pelajar, Yogyakarta, 2005.

Yuarsi Susi Eja, et.al., Menggagas Tempat yang Aman Bagi Perempuan, Pusat Studi Kependudukan dan Kebijakan Universitas Gajah Mada, Yogyakarta, 2002. 
B. Law Journal / Scientific:

Andri Winjaya Laksana, Keadilan Restoratif Dalam Penyelesaian Perkara Anak yang Berhadapan Dengan Hukun Dalam Sistem Peradilan Pidana Anak, Jurnal Pembaharuan Hukum, Volume IV No. 1, January-April 2017.

Ira Alia Maerani, Desember 2015, Reaktualisasi Proses Penyidikan Oleh Kepolisian Berbasis Nilai-nilai Pancasila dan Optimalisasi Peman-faatan Teknologi, Jurnal Hukum, Vol. XXXII, No. 2, Faculty of law Sultan Agung Islamic University (UNISSULA), Semarang.

Sri Rahmi, Aswanto, dan Muh. Syukri, Penerapan Keadilan Restoratif Dalam Sistem Peradilan Pidana Anak Di Kota Makasar (Suatu Pembaruan Hukum Acara Pidana Anak), Faculty of law, Post graduate Program University of Hasanuddin, Makasar, without year. 